\title{
KOMUNIKASI POLITIK NABI MUHAMMAD SAW TERHADAP PERJANJIAN HUDAIBIYAH (ANALISIS SURAT PERJANJIAN HUDAIBIYAH DALAM PERSPEKTIF JURNALISTIK)
}

\author{
Oleh: SUF KASMAN \\ UIN Alauddin Makassar \\ sufkasman@gmail.com
}

\begin{abstract}
This is the art of diplomacy (rather politics itself) and in the history of mankind the treaty of Hudaibiyah is one of the most perfect paradigm of this art. It was for a reason that Allah referred to it as a "manifest victory" and a "mighty help". The backbone of treaties concluded between Muslims and non-Muslims in the pre-modern era.This research is to investigate Prophet Muhammad pattern of communicating withindividuals and masses. Hudaibiyah treaty between Prophet Muhammad and Qoraish was a beginning of a newphase in the prophet's journey to accomplish his mission and preach his call for thedivine faith to all nations. The prophet planned to spread the message of Islam beyond Arabia.
\end{abstract}

Keywords: Communication Political, Prophet Muhammad, Treaty of Hudaibiyah, and Journalism

\section{PENDAHULUAN}

Muhammad SAW adalah seorang komunikator ulung nan handal. Seorang teladan luar biasa yang sepantasnya semua manusia wajib meniru akhlak \& cara berkomunikasinya. Muhammad SAW merupakan sosok yang fasih dalam metakomunikasi. ${ }^{1}$ Sedikit bicara namun penuh makna, memiliki komunikasi yang halus; mudah dimengerti, dan tidak menyinggung perasaan orang yang diajak berkomunikasi. Beliau selalu memberi banyak inspirasi, motivasi, inovasi, dan harapan yang penuh pencerahan dan kedamaian. ${ }^{2}$

Bahkan ketika melakukan komunikasi politik dengan para dedengkot Musyrikin Quraysi, Muhammad SAW selalu menggunakan komunikasi yang indah dan gaya bicara yang santun sehingga siapa pun menyimaknya tidak akan tersinggung. Sungguh tepat penyair besar bernama Ahmad Syauqi yang dikutip oleh Ismail, menyebutkan bahwa "Muhammad SAW sebagai hidâyah (petunjuk), komunikasi demi komunikasi religiusnya tertata berada pada puncak ketinggian

\footnotetext{
${ }^{1}$ A. Muis, Komunikasi Islami. Cet. I; (Bandung: PT Remaja Rosdakarya, 2001), h. 39. Metakomunikasi adalah suatu komentar terhadap isi pembicaraan dan sifat hubungan antara yang berbicara, yaitu pesan di dalam pesan yang menyampaikan sikap dan perasaan pengirim terhadap pendengar.

${ }^{2}$ Faisal Ismail, Sejarah \& Kebudayaan Islam; Periode Klasik (Abad VII-VIII M). Cet. I.; (Yogyakarta: IRCiSoD, 2017), h. 89.
} 
semua makhluk. Muhammad SAW juga sampai membuat julukan-julukan indah untuk tiap sahabatnya, hingga istri-istrinya". ${ }^{3}$ Al-Yahsubi menambahkan "berkah buah pikiran \& kecerdasan Muhammad SAW yang dipadu ketajaman inderanya, kefasihan bicaranya hingga kehebatan nalurinya, maka tidaklah dapat disangkal bahwa Beliau adalah orang yang paling cerdas dan cerdik dalam berkomunikasi". ${ }^{4}$

Pemilihan kata-kata yang baik dan santun dipadu prilaku jujur dan baik memang juru kunci tercapainya tujuan dan terwujudnya komunikasi yang efektif. Sehingga seluruh masyarakat Mekah sepakat memberi Muhammad SAW gelar AlAmîn (yang sangat terpercaya). ${ }^{5}$ Amarah yang meluap-luap dari pihak musuhseketika itu padam-saat berhadapan dengan sikap santun dan tutur kata yang lembutnya Muhammad SAW. Sebaliknya, kasih sayang dapat berganti menjadi aneka kebencian, kekerabatan menjadi permusuhan akibat tutur kata yang kasar dan menusuk perasaan. ${ }^{6}$ Prinsip kesantunan itulah yang didemonstrasikan Muhammad SAW melalui perjanjian tertulis yang dikenal dengan "Perjanjian Hudaibiyah", mengedepankan akhlak dan komunikasi politik, namun religius.

Pada diplomasi (baca: komunikasi politik) Hudaibiyah, Muhammad SAW tidak pernah berhenti mengedepankan prilaku etis, demokratis, pluralis, inklusif, santun dan bijak. Kendati pemimpin Quraysi selalu berusaha menghalang-halangi visi \& misi suci Muhammad SAW. Semakin bertambahnya jumlah pengikut Muhammad SAW, semakin keras pula tantangan dilancarkan kaum Quraysi. ${ }^{7}$ Sejauhar itulah menuai kesuksesan luar biasa dalam pengembangan dakwahnya di kemudian hari. Semua lahir dari kemampuan menahan diri dari meraih

\footnotetext{
${ }^{3}$ Faisal Ismail, Sejarah \& Kebudayaan Islam..., h. 89.

${ }^{4}$ Qadhi 'Iyâd Ibn Mûsa Al-Yahsubi, Muhammad Messengnge of Allah Ash-Shifa of Qodi yang dialihbahasakan oleh Gufron A. Mas'adi dengan judul "Keagungan Kekasih Allah Muhammad SAW; Keistimewaan Personal Keteladanan Berisalah”. Cet. I; (Jakarta: PT RajaGrafindo, 2002), h. 59.

${ }^{5}$ Faisal Ismail, Sejarah \& Kebudayaan Islam..., h. 104. Ada saja sebagian kaum Orientalis Barat yang mengatakan bahwa gelar "Al-Amîn" itu diambil dari nama ibunya, yaitu Aminah. Apabila diteliti pendapat tersebut secara seksama, hal itu tidak mempunyai dasar sama sekali. Sebab pemberian nama atau gelar pada seseorang dengan nama ibu adalah tidak lazim bagi bangsa Arab. Tidak mustahil ada motif-motif tertentu yang bersifat tendensius pada sementara kaum Orientalis itu; mereka hendak menghapus dan mengaburkan sifat-sifat jujur dan pribadi luhur yang selalu memancar pada sosok pribadi Muhammad SAW.

Ilmuwan Sadillo yang dikutip Faisal Ismail mengatakan "Karena baiknya akhlak Muhammad terhadap masyarakat, Beliau pada usia 25 tahun diberi gelar Al-Amîn. Sementara William Muir mengatakan "bahwa Muhammad diberi gelar Al-Amîn dengan suara bulat oleh seluruh penduduk Mekah karena ketinggian budinya dan kemuliaan akhlaknya. Muir menerjemahkan kata Al-Amîn dalam bahasa Inggris, faithful. Lih. Faisal Ismail, Sejarah \& Kebudayaan Islam..., h. 104-105.

${ }^{6}$ A. Muis, Komunikasi Islami..., h. 39

${ }^{7}$ Badri Yatim, Sejarah Peradaban Islam. Cet. XXVIII; (Depok: PT RajaGrafindo Persada, 2017), h. 20 .
} 
keuntungan jangka pendek hari ini, demi keuntungan yang lebih besar di masa depan. Muhammad SAW tidak mau mengembangkan dakwahnya melalui jalan kekerasan, bahkan Beliau tidak ridha pada tindak kejahatan sejenis pembunuhan. Malah dinyatakan tidak ada kejahatan yang menandingi kemusyrikan kepada Allah selain mengganggu orang lain. Mengganggu orang saja sudah begitu beratnya, apalagi membunuh dan melenyapkan hidup orang. ${ }^{8}$ Eksistensinya melaksanakan semata-mata tugas kerasulannya berdasarkan pada petunjuk wahyu Ilahi, dan tugas mulia tersebut dijalankan dengan penuh kesabaran dan keikhlasan, yang tidak mudah terbawa emosi.

Ketika Muhammad SAW menerima poin demi poin isi Perjanjian Hudaibiyah oleh jebakan Musyrikin Quraysi, hampir semua sahabat demonstrasi melakukan protes atas content (isi) rumusan perjanjian melalui kemasan jurnalistik itu. Klimaksnya ketika Muhammad SAW dipaksa mengganti content dari "Muhammad Rasulullah" menjadi "Muhammad, putera Abdullah" supaya kaum Quraysi menduga itulah babak permulaan kemenangan mereka. ${ }^{9}$

Lewat Perjanjian Hudaibiyah, Nabi Muhammad SAW mencontohkan bagaimana seorang Muslim harus berkomitmen terhadap perjanjian. Meskipun membawa risiko yang amat berat, Muhammad SAW tetap setia dengan kesepakatan yang dijalin. ${ }^{10}$ Itulah komunikasi politik level tingkat tinggi merupakan bagian pribadi Muhammad SAW yang tercipta dari adonan rahmat. Dan Beliau-untuk Beliau shalawat Allah dalam salamNya-terpekik riang gembira karena komunikasinya tuntunan Ilahi, melakukan komunikasi dengan kawalan wahyu Ilahi itu dengan penuh bijaksana dan secara cerdik akan menerima perjanjian Hudaibiyah tersebut.

Bertolak dari masalah tersebut, penulis mencoba menggambarkan permasalahan dengan memfokuskan pada komunikasi politik Nabi Muhammad SAW terhadap perjanjian Hudaibiyah melalui "perjanjian tertulis" melalui kemasan media jurnalistik.

Orang-orang yang merasa dirinya pernah disakiti/ dicurangi oleh lawanlawannya, biasanya tidak butuh perjanjian damai terhadap orang yang memusuhinya. Di sinilah permasalahan itu muncul, "Mengapa Muhammad SAW sangat memperhatikan aspek perjanjian damai (baca: perjanjian tertulis)" terhadap orang yang memusuhinya (Musyrikin Quraysi), padahal Musyrikin Quraysi mencurangi aturan main dalam kesepakatan Perjanjian Hudaibiyah. ${ }^{11}$

\footnotetext{
${ }^{8}$ Khâlid Muhammad Khâlid, Al-Insâniyah Muhammad yang dialihbahasakan oleh Salim Basyarahil dengan judul "Muhammad Rasulullah Juga Manusia Biasa". Cet. I.; (Jakarta: Pustaka Firdaus, 1992), h. 25.

${ }^{9}$ Fuad Hashem, Sirah Muhammad Rasulullah Kurun Mekah. Cet. IV; (Bandung: Mizan, 1995), h. 136.

${ }^{10}$ Khâlid Muhammad Khâlid, Al-Insâniyah Muhammad,... h. 3.

${ }_{11}$ Mahmud Syalabi, Syakhshiyyah Rasûlullâh SAW. Cet. I.; (Beirut: Jamî'u Al-Huqûqi Mahfûzhati Lî Dâr Al-Jîl, 1412 H/1992), h. 13.
} 
Tujuan umum yang ingin dicapai di dalam penelitian ini adalah untuk menganalisis komunikasi politik Nabi Muhammad SAW terhadap perjanjian Hudaibiyah dalam kemasan jurnalistik. Perjanjian yang ditandatangani di lembah Hudaibiyah itu melalui dukungan moral dan politik antara kaum Muslimin Madinah dengan Musyrikin Quraysi Mekah.

Adapun tujuan khusus pada makalah ini sebagai berikut:

1. Untuk mengetahui kepiawaian Muhammad SAW yang sangat jitu dalam komunikasi politik pada perjanjian Hudaibiyah,

2. Untuk mengetahui kemampuan Muhammad SAW dalam berdiplomasi (berkomunikasi politik), dan menghindari kekerasan, untuk mengatasi perselisihan baik antara individu maupun dalam lingkup yang lebih besar yaitu negara, yaitu sebagai langkah antisipasi dari propaganda dan serangan bertubi-tubi Musyrikin Quraysi yang sudah lama memiliki niat ingin memporakporandakan umat Islam.

\section{TINJAUAN TEORITIS}

Komunikasi secara umum dapat dipahami sebagai proses transmisi informasi berupa kode (tanda) atau simbol-simbol yang dikonstruki untuk memunculkan makna tertentu, kata-kata, gambar, figur, grafik dan semacamnya yang terjadi diantara dua orang atau lebih dengan tujuan untuk dapat mengubah prilaku orang lain (komunikan). Komunikasi pada hakikatnya adalah suatu proses sosial, yaitu sesuatu yang berlangsung antar manusia untuk membangun kebersamaan dengan membentuk perhubungan dengan orang lain. ${ }^{12}$ Fiske menyebutnya, definisi di atas hanyalah secuil diantara sekian banyaknya definisidefinisi komunikasi yang lain, sebab komunikasi memiliki variasi definisi yang tidak terhingga. ${ }^{13}$

Politik berasal dari bahasa Yunani yang berarti seni mengatur dan mengurus negara dan ilmu kenegaraan. Politik mencakup kebijaksanaan/ tindakan yang bermaksud mengambil bagian dalam urusan kenegaraan/pemerintahan termasuk yang menyangkut penetapan bentuk, tugas dan lingkup urusan negara. Mengurus negara/pemerintahan dapat dijalankan dengan dengan cara, aturan dan hukum yang berbeda-beda, misalnya secara demokratis, liberal, otoriter,

\footnotetext{
${ }^{12}$ Anwar Arifin, Strategi Komunikasi; Sebuah Pengantar Ringkas. Cet. I; (Bandung: CV ARMICO, 1984), h. 13-14.

${ }^{13}$ John Fiske, Introduction to Communication Studies yang dialihbahasakan oleh Hafsari Dwiningtyas dengan judul "Pengantar Ilmu Komunikasi”. Cet. II. (Jakarta: PT RajaGrafindo Persada, 2012), h. 1.
} 
diktatorial, machiavelistis atau etis. ${ }^{14}$ Meminjam istilah Nimmo, bahwa politik merupakan sebuah ilmu pemerintah serta mengatur masyarakat manusia di dalamnya, termasuk hubungan antara negara terhadap warga negaranya dan juga Negara lain. ${ }^{15}$

Perlu disederhakan bahwa penelitian ini, politik endingnya untuk mengartikan "kegiatan orang secara kolektif yang mengatur perbuatan mereka di dalam kondisi konflik sosial. Politik harus dijalankan pada prinsip-prinsip kebaikan serta kebenaran, yang dalam konteks Islam disebut sebagai prinsip dakwah. $^{16}$

Adapun komunikasi tentu bertaut erat dengan politik, jika diakumulasi menjadi "komunikasi politik" wujudnya sebuah proses interaktif mengenai transmisi informasi di antara para politisi, media dan publik, dimana informasi digabungkan ke dalam karya kolektif dan hubungan kekuasaan yang saling mengisi. Lalu akan diuraikan sumber, saluran, dan pesan komunikasi untuk belajar politik. ${ }^{17}$ Jika tidak, politik akan bersifat kontra produktif terhadap terwujudnya kehendak bersama sebagai masyarakat utama. ${ }^{18}$

Perjanjian secara etimologis perjanjian (yang dalam bahasa Arab diistilahkan dengan mu'ahadah ittifa', akad), atau overeenkomst (Belanda) dan contract (Inggris) dapat diartikan sebagai: "perjanjian atau persetujuan adalah suatu perbuatan dimana seseorang atau lebih mengikatkan dirinya terhadap seseorang lain atau lebih"

Ada dua macam teori yang membahas tentang pengertian perjanjian. Menurut teori lama yang disebut perjanjian adalah perbuatan hukum berdasarkan kata sepakat untuk menimbulkan akibat hukum. Dari definisi tersebut telah tampak adanya konsensualisme dan timbulnya akibat hukum (tumbuh atau lenyapnya hak dan kewajiban. Menurut teori baru yang dikemukakan oleh Van Dunne yang dikutip Tutik, "Perjanjian adalah suatu hubungan hukum antara dua pihak atau lebih berdasarkan kata sepakat untuk menimbulkan akibat hukum. ${ }^{19}$

Hudaibiyah adalah nama sebuah tempat kira-kira 6 kilometer dari kota Mekah. Kawasan Hudaibiyah tersebut juga dikenal sebagai daerah perbatasan

\footnotetext{
${ }^{14}$ B.N. Marbun, Kamus Politik. Cet. II; (Jakarta: Pustaka Sinar Harapan, 2003), h. 444-445.

${ }^{15}$ Dan Nimmo, Political Communication and Public Opinion in America, yang dialihbahasakan oleh Tjun Surjaman dengan judul "Komunikasi Politik". Cet. I; (Bandung: Remaja Karya CV Bandung, 1989), h. 8.

${ }^{16}$ Amin Rais, Refleksi Amin Rais: dari Persoalan Semut Sampai Gajah. Cet. I; (Jakarta: Gema Insani Press, 1997), h. 87.

${ }^{17}$ Dan Nimmo, Political Communication and Public Opinion in America, yang dialihbahasakan oleh Tjun Surjaman dengan judul "Komunikasi Politik". Cet. V; (Bandung: Remaja Karya CV Bandung, 1989), h. 86.

${ }^{18}$ Undang A. Kamaluddin \& Muhammad Alfan, Dinamika Politik Di Indonesia: Perjalanan Politik Sejak Orde Lama Hingga Reformasi. Cet. I; (Bandung: Pustaka Setia, 2015), h. 37.

${ }^{19}$ Titik Triwulan Tutik, Hukum Perdata dalam Sistem Hukum Nasional. Cet. I; (Jakarta: Kencana, 2010), h. 222.
} 
Tanah Haram sehingga sering dijadikan tempat miqat bagi orang yang menunaikan ibadah umrah. Penyebutan nama Hudaibiyah sebenarnya diambil dari nama sebuah sumur, ada pula menyebutnya sebuah telaga yang sekarang ini dikenal telaga Asy-Syumaisi. Tempat ini menjadi bersejarah karena Muhammad SAW telah membuat perjanjian dengan mengadakan gencatan senjata bersama dedengkot para pembesar Mekah (Musyrikin Quraysi).

Jurnalistik merupakan suatu seni kejuruan yang bersangkutan dengan pemberitaan dan persuratkabaran. ${ }^{20}$ Dengan kata lain seni dan profesi dengan tanggung jawab profesional-art and craft with prosesional responsibilities-yang mensyaratkan wartawannya melihat dengan mata yang segar-eyes that see-pada setiap peristiwa untuk menangkap aspek-aspek yang unik. Tetapi mata itu harus mempunyai fokus, suatu arah untuk mengawali pandangan. ${ }^{21}$ Lalu dicatat kemudian dilaporkan dalam kemasan berita (peristiwa factual (fact) atau pendapat seseorang (opini) kepada khalayak. ${ }^{22}$ Kasman mengatakan bahwa "Definisi jurnalistik itu jumlahnya begitu banyak. Namun jurnalistik mempunyai fungsi sebagai pengelolaan laporan harian yang menarik minat khalayak, mulai dari peliputan sampai penyebarannya kepada masyarakat mengenai apa saja yang terjadi di dunia". ${ }^{23}$

\section{Pengakuan Para Ilmuwan Mengenai Paripurna Muhammad SAW}

Orang-orang yang bersikap obyektif dari kalangan non Muslim telah mengakui hal ini. Barghisy telah mengakumulasi segelintir ilmuwan tersebut melalui bukunya, A'zham Insân 'Arafathu Al-Basyariyyah, Akhlâquhu wa Kaifa Nuhibbuhu wa Nanshuruhu. ${ }^{24} \mathrm{Di}$ antara yang mengakuinya adalah kaum orientalis dari berbagai negara belahan dunia ini, seperti orientalis Amerika, Washington Irfing, ${ }^{25}$ dia berkata "Muhammad adalah penutup para nabi, Rasul paling agung yang diutus oleh Allah untuk menyeru manusia kepada penyembahan Allah

\footnotetext{
${ }^{20}$ Penyusun Departemen Ilmu Komunikasi Fakultas Ilmu-Ilmu Sosial Universitas Indonesia, Kamus Istilah Jurnalistik. Cet. I.; (Jakarta: Progres, 2003), h. 57.

${ }^{21}$ Luwi Ishwara, Catatan-catatan Jurnalisme Dasar. Cet. III; (Jakarta: Buku Kompas, 2007), h. 17.

${ }^{22}$ Suf Kasman, Jurnalisme Universal; Menelusuri Prinsip-Prinsip Da'wah bi Al-Qalam Dalam Al-Qur'an. Cet. I. (Jakarta: Teraju, 2004), h 23.

${ }^{23}$ Suf Kasman, Pers dan Pencitraan Umat Islam di Indonesia; Analisis Isi Pemberitaan Kompas dan Republika. Cet. I; (Jakarta: Badan Litbang dan Diklat Kementerian Agama RI, 2010), h. 55.

${ }^{24}$ Hisyam Muhammad Sa'id Barghisy, A'zham Insân 'Arafathu Al-Basyariyyah, Akhlâquhu wa Kaifa Nuhibbuhu wa Nanshuruhu yang dialihbahasakan oleh Izzuddin Karimi dengan judul "Manusia Teragung Sepanjang Masa, Nabi Muhammad SAW; Potret Keagungan Akhlak dan Kepribadian Rasulullah SAW Serta Bagaimana Mencintai dan Membela Beliau. Cet. IV.; (Jakarta: Darul Haq, 2016), h. 3-4.

${ }^{25}$ Washington Irfing, adalah salah seorang penulis besar Amerika yang menjadi kebanggaan Amerika Serikat dan negera-negara lain di abad ke XIX Masehi, lahir th. 1832 M. di kota Washington dan meninggal thn. $1892 \mathrm{M}$.
} 
melalui komunikasi religiusnya".

Orientalis Spanyol Jan Lek, ${ }^{26}$ dalam bukunya Al-Arab berkata, "Tidak mungkin kehidupan Muhammad digambarkan dengan sifat yang lebih baik daripada apa yang telah Allah nyatakan dalam FirmanNya, "Dan Kami tidak mengutusmu kecuali sebagai rahmat bagi alam semesta” (QS. Al-Anbiyâ': 107). Muhammad adalah rahmat yang sebenarnya dan sungguh aku bershalawat (mendoakannya) dengan semangat dan kerinduan."

Seorang orientalis Italia, Loravicia Vaghleri, ${ }^{27}$ berkata, "Muhammad yang selalu berpegang kepada dasar-dasar llahiyah adalah seorang laki-laki dengan toleransi yang tinggi, komunikasi yang beradab, khususnya kepada para pengikut agama-agama samawi. Dia tahu bagaimana menggunakan kesabaran sebagai perisai dalam menghadapi para penyembah berhala, dia selalu menghiasi diri dengan sikap perlahan tapi mantap".

Orientalis Perancis Gustave Le Bon, ${ }^{28}$ berkata, "Muhammad menghadapi berbagai macam siksaan dan tekanan dengan sabar dan lapang dada. Muhammad telah memperlakukan Quraysi yang memusuhinya selama dua puluh tahun dengan lembut dan santun."

Para Filosof juga mengakui hal yang sama. Di antara mereka adalah seorang Filosof Inggris, George Bernard Shaw, ${ }^{29}$ dia berkata, "Aku telah membaca kehidupan Rasul Islam dengan baik, berkali-kali dan berkali-kali, dan aku tidak menemukan kecuali akhlak-akhlak luhur yang semestinya, komunikasi yang tertata nan santun, dan aku sangat berharap Islam menjadi jalan bagi dunia". ${ }^{30}$

Kaum orientalis di atas telah berusaha membagi babakan sejarah Muhammad SAW selama di Mekah dalam tiga atau empat babak: paling awal, awal, pertengahan dan terakhir. ${ }^{31}$

Bahkan dalam Perjanjian Lama yang dikutip Benjamin, didapati sabda Tuhan, bahwa "Pengunungan Paran, Kedar serta domba-domba dan 10.000

\footnotetext{
${ }^{26}$ Jan Lek seorang orientalis Spanyol yang tersohor, lahir $182 \mathrm{M}$ dan wafat $1897 \mathrm{M}$

${ }^{27}$ Loravicia Vaghleri, seorang orientalis perempuan asal Italia dan pengkaji sejarah Islam dan bahasa Arab, di antara buku-bukunya adalah Qawâ'id al- 'Arabiyah, Al-Islam dan Difa' an AlIslâm.

${ }^{28}$ Gustave Le Bon, seorang orientalis Perancis, lahir th. $1841 \mathrm{M}$, di antara buku-bukunya yang paling terkenal adalah Hadharah Al- 'Arab, yang tergolong buku induk yang lahir di zaman modern di Eropa, buku ini menilai peradaban Arab Islam dengan obyektif, meninggal thn. 1921 M.

${ }^{29}$ George Bernard Shaw, seorang penulis alur cerita film dari Inggris yang terkenal, lahir di Irlandia, meraih Nobel di bidang sastra th. $1920 \mathrm{M}$.

${ }^{30}$ Hisyam Muhammad Sa'id Barghisy, A'zham Insân 'Arafathu Al-Basyariyyah, Akhlâquhu wa Kaifa Nuhibbuhu wa Nanshuruhu yang dialihbahasakan oleh Izzuddin Karimi dengan judul "Manusia Teragung Sepanjang Masa, Nabi Muhammad SAW; Potret Keagungan Akhlak dan Kepribadian Rasulullah SAW Serta Bagaimana Mencintai dan Membela Beliau. Cet. IV.; (Jakarta: Darul Haq, 2016), h. 4.

${ }^{31}$ Fuad Hashem, Sirah Muhammad Rasulullah ..., h. 132.
} 
pengikutnya menuju rumah Tuhan menjadi saksi kebenaran Muhammad yang tak terbantahkan"32.

Keparipurnaan nama Muhammad SAW di sini, melampaui batas pujian. Karena rasa cinta \& kagum yang meluap-luap, Beliau berjerih payah melawan keangkaramurkaan mereka yang hendak menggalakkan rasa keputusasaan. Muhammad SAW tahu pasti bahwa rahmat itu bukan soal sekunder, bukan kemewahan, akan tetapi merupakan soal primer yang mutlak perlu. Adapun orang yang paling patut mendapatkannya adalah orang yang paling membutuhkannya. ${ }^{33}$

\section{Perjanjian Hudaibiyah, Muhammad SAW Mengembangkan Dakwah Melalui Komunikasi Politik}

Prestasi begitu gemilang dari Muhammad SAW-utusan Tuhan terakhir ini yang dalam waktu singkat-mampu mentransformasikan suatu masyarakat yang heterogen ke dalam satu ummah, sementara Muhammad SAW juga harus menjaga dirinya dari berbagai bahaya eksternal. Muhammad SAW pun harus menanamkan benih-benih keruhanian ke dalam hati sanubari dan jiwa para sahabatnya yang saleh, yang menebarkan harumnya nilai keruhanian Islam kepada generasigenerasi berikutnya. ${ }^{34}$

Keberhasilan Muhammad SAW mengembangkan dakwahnya dalam momen Perjanjian Hudaibiyah paling tidak ditunjang oleh tiga faktor utama:

Pertama, ide-ide \& komunikasi religius yang selalu tertuntun wahyu Ilahi. Ide-ide \& komunikasi religius itu sesuai dengan kodrat manusia, lalu ditujukan kepada seluruh umat manusia, bukan kepada segelintir suku atau bangsa tertentu. Karena itu ide-ide \& komunikasi Islam (religius) itu bersifat universal, cocok untuk manusia kapan dan dimanapun mereka berada. Sebab, itu agama Islam tidak mengenal apa yang disebut sociale vacuum (kekosongan sosial). Ajaran-ajarannya dapat berlaku pada seluruh masyarakat.

Kedua, terletak pada kepribadian dan kepemimpinan Muhammad SAW. Tidak dapat disangkal, Muhammad SAW memiliki sifat-sifat kepribadian yang agung. Beliau memiliki integritas kepribadian yang amat tinggi "rahmatan li al'âlamîn". Abu Bakar Muhammad ibn Thâhir yang dikutip Al-Yahsubi mengatakan "Allah mengaruniakan Rahman dan seluruh sifat-sifatNya kepada Nabi Muhammad SAW sebagai rahmat bagi seluruh makhluk. ${ }^{35}$ Abû Layth Al-

\footnotetext{
${ }^{32}$ David Benjamin Keldani (Abdul Ahad Dawud), Muhammad in the Bible yang dialihbahasakan oleh Burhan Wirasubrata dengan judul "Menguak Misteri Muhammad SAW". Cet. XIII;

(Jatiwaringin, PT Sahara Intisains, 2006), h. 34.

${ }^{33}$ Khâlid Muhammad Khâlid, Al-Insâniyah Muhammad,... h. 29.

${ }^{34}$ Seyyed Hossein Nashr, Muhammadi Trust, Muhammad Man of Allah..., h. 48.

${ }^{35}$ Qadhi ‘Iyâd Ibn Mûsa Al-Yahsubi, Muhammad Messengnge of Allah...h. 7.
} 
Samarqandi menjelaskan rahmatan li al- 'âlamîn dengan dua alam, yaitu alam jin dan alam manusia. ${ }^{36}$

Ketiga, partisipasi para sahabat Beliau. Para sahabatnya berjuang dengan gigih, membantu Beliau berupa harta kekayaan, maupun dengan pandangan pikiran mereka, Beliau selalu musyawarah dengan para sahabat dalam hal-hal yang bertalian dengan masalah sosial kebudayaan. ${ }^{37}$

\section{Asal Muasal Perjanjian Hudaibiyah}

Kendatipun kini kota Madinah sudah menjadi pusat Islam yang mapan, daya tarik kota Mekah masih begitu kuat, khususnya karena Tuhan telah menetapkan ibadah haji ke kota lama Nabi Ibrahim as itu sebagai bagian dari ibadah wajib dalam agama baru ini. Muhammad SAW memendam keinginan yang mendalam untuk melakukan ibadah haji bersama umatnya. Muhammad SAW pun berangkat menuju "Rumah Tuhan", bergerak dengan iring-iringan besar menuju Mekah.

Penduduk Mekah, yang merasakan adanya bahaya dengan kehadiran Muhammad SAW ke dalam kota, seketika itu serta merta langsung menghalangi Muhammad SAW untuk memasuki kota kelahirannya. Dengan demikian, Muhammad SAW kemudian dipaksa untuk berkema di luar kota Mekah, di daratan yang disebut Hudaibiyah. Muhammad SAW berpikir bahwa barangkali persoalan ini dapat diselesaikan dengan cara musyawarah, sehingga kemudian Muhammad SAW mengirimkan Utsman bin 'Affân sebagai utusannya untuk berbicara dengan penduduk Mekah serta menunggu jawaban dari mereka (Musyrikin Quraysi). ${ }^{38}$

Namun, utusan tersebut tidak segera kembali sebagaimana yang diharapkan, dan hal ini menimbulkan persoalan besar bagi diri Muhammad SAW dan pengikutnya. Mereka tidak dapat kembali ke Madinah tanpa adanya jawaban, dan tidak pula dapat masuk ke dalam kota tanpa suatu perjuangan senjata yang tidak mereka siapkan, sebab mereka datang dengan semangat untuk melakukan ibadah. Setiap orang menyadari sifat kritis dari konfrontasi ini. Para sahabat kemudian mendatangi Muhammad SAW, dan mereka berjanji di bawah sebuah pohon, bersumpah untuk membela Muhammad SAW \& Islam hingga titik darah penghabisan. Terjadilah suatu ikatan kesetiaan serta janji baru yang dibuat antara Muhammad SAW dan masyarakat Muslim yang masih baru pada waktu itu, yang sangat penting artinya bagi sejarah masyarakat Islam di kemudian hari. Pada detik-detik terakhir sebelum Muhammad SAW membuat keputusan final dengan berbagai konsekuensinya dalam krisis tersebut, penduduk Mekah memberikan

\footnotetext{
${ }^{36}$ Qadhi 'Iyâd Ibn Mûsa Al-Yahsubi, Muhammad Messengnge of Allah...h. 8.

${ }^{37}$ Tim Penyusun Naskah pada Proyek Pembinaan Perguruan Tinggi Agama/IAIN Alauddin Ujung Pandang tahun anggaran 1981/1982, h. 43-44.

${ }^{38}$ Seyyed Hossein Nashr, Muhammadi Trust, Muhammad Man of Allah..., h. 48-49.
} 
jawaban bahwa mereka akan mengizinkan umat Islam melakukan ibadah umrah, jika ibadah ini ditunda pelaksanaanya hingga tahun depan. Dengan keputusankeputusan besar yang bersifat diplomatis, yang mencerminkan sikap kenegarawanan yang luar biasa, Muhammad SAW menerima tawaran itu, dan suatu gencatan senjata pun disetujui, peristiwa ini dikenal sebagai Perjanjian Hudaibiyah. ${ }^{39}$

\section{Isi Perjanjian Hudaibiyah}

Adapun isi dari Perjanjian Hudaibiyah adalah sebagai berikut:

1. Kedua belah pihak setuju untuk mengadakan gencatan senjata. Tidak saling menyerang antara kaum Muslimin dengan penduduk Mekah selama sepuluh tahun. Poin ini penting bagi kaum Muslimin agar tercipta rasa aman. Artinya, Kaum Muslimin tidak khawatir akan mendapat serangan Quraysi yang juga menjadi jalan untuk Islam lebih menyebar. Bukankah orang-orang Quraysi yang menjadi musuh utama orang Islam sudah tunduk dalam perjanjian. ${ }^{40}$

2. Jika ada warga Madinah yang menyeberang kawasan Mekah maka tidak diperbolehkan kembali ke Madinah.

3. Barang siapa dari masyarakat Arab di luar perjanjian mengadakan persekutuan dengan Muhammad diperbolehkan, dan barang siapa dari masyarakat Arab di luar perjanjian mengadakan persekutuan dengan Quraysi diperbolehkan

4. Kaum Muslimin yang menempuh perjalanan ke Mekah, namun harus berpulang tanpa menunaikan haji. Maka untuk tahun berikutnya mereka hanya diperbolehkan 3 hari di Mekah (tak cukup untuk berhaji). ${ }^{41}$

\section{Hikmah dari Perjanjian Hudaibiyah}

Al-Qur'an menyebutnya "fathan mubîna" (kemenangan yang nyata). Di antara bukti-bukti kemenangan sebagai berikut:

1. Perjanjian Hudaibiyah merupakan pertanda mulai munculnya pengakuan kaum Quraysi terhadap eksistensi kaum Muslimin. Terbukti, dalam penandatangan perjanjian damai itu mereka mensikapi kaum Muslimin sebagaima seorang musuh terhadap musuhnya. Padahal, sebelumnya mereka sangat memandang rendah dan meremehkan umat Islam. Perubahan sikap ini, tentu saja segera terdengar dan menggegerkan seluruh jazirah Arabia.

\footnotetext{
${ }^{39}$ Seyyed Hossein Nashr, Muhammadi Trust, Muhammad Man of Allah..., h. 49-50.

${ }^{40}$ https://www.republika.co.id/berita/dunia-islam/islam-digest/18/07/27/pciqn8313-belajar-darihudaibiyah

${ }^{41}$ https://islami.co/perjanjian-hudaibiyah-diplomasi-nabi-untuk-kerukunanmadinah-mekah/
} 
2. Perjanjian damai ini semakin menguatkan niat kabilah Khuza'ah untuk mengumumkan secara terang-terangan koalisi mereka dengan kaum Muslimin. Sebelumnya, mereka masih menyembunyikan simpati mereka terhadap kaum Muslimin.

3. Penandatanganan perjanjian damai ini membuka kesempatan bagi kaum Muslimin untuk lebih memusatkan perhatian mereka pada upaya menghadapi ancaman Yahudi di Khaibar: Sebab, mereka saat itu merupakan sumber bahaya terbesar yang mengancam keberadaan kaum Muslimin. Apalagi, para pemuka Yahudi Khaibar adalah orang-orang yang berperan besar dalam menggalang konsipirasi dan persekutuan untuk memerangi kaum Muslimin dalam perang Khandaq.

4. Perdamaian Hudaibiyah juga memberi kesempatan kepada umat Islam untuk menyebarkan Islam secara lebih luas. Ibn Syihab-Zuhri menggambarkan hal ini sebagaimana berikut;

Ketika perjanjian damai telah disepakati, peperangan tak terjadi lagi, setiap orang merasa aman, dan mereka dapat bertemu, berdialog dan juga berdebat dengan leluasa, sehingga tak ada seorang pun yang menyanggah ketika di ajak masuk Islam. Bahkan. hampir semuanya masuk ke dalam pangkuan Islam dengan penuh kerelaan. Walhasil jumlah orang yang memeluk Islam dalam kurun waktu dua tahun tersebut, hampir sama dengan jumlah umat Islam sebelum Hudaibiyah. Buktinya, saat terjadi perjanjian Hudaibiyah, Nabi membawa serta para sahabatnya yang berjumlah sekitar 1400 orang. Kemudian, pada saat terjadi penaklukan Mekah, yakni dua tahun setelah perjanjian itu, jumlah umat Islam sudah mencapai 10.000 orang lebih. ${ }^{42}$

Itulah beberapa hikmah di balik pentingnya menundukkan akal (penalaran) kepada kebijakan yang telah ditetapkan oleh teks-teks suci. Betapapun, mentaati dan mematuhi keputusan Muhammad SAW adalah wajib, walaupun keputusan itu secara lahir sangat bertolak belakang dengan akal dan tuntutan pemahaman nalar. Karenanya, setiap Mukmin harus yakin dengan seyakin-yakinnya, bahwa segala yang diperintahkan Allah dan Rasul-Nya adalah selalu membawa kepada kebaikan dan kemaslahatan mereka. Kaum beriman juga harus percaya, bahwa putusan itu merupakan yang terbaik dan paling bijaksana, meski akal mereka tidak mampu menyibak tujuan dan manfaat di balik kebijakan itu.

Dan akhir dari ujian keimanan yang sangat sulit ini, yaitu setelah gejolak hati mereka mereda, adalah sebagaimana yang difirmankan Allah kepada

\footnotetext{
${ }^{42}$ Muhammad Amahzun, Manhajun Nabiyy fì al-Da'wah min Khilâli al-Sîrah al-Shahîhah: AlMa'rifah, al-Tarbiyah, Al-Thakhthîth, Al-Tanzhîm. Cet. I.; (Mesir: Dâr al-Salâm, 1423 H/2002), h. 233-236.
} 
Muhammad SAW saat kembali ke Madinah bersama rombongan kaum Muslimin. ${ }^{43}$ Allah berfirman,

Sungguh, Kami telah memberikan kepadamu kemenangan yang nyata. Agar Allah memberikan ampunan kepadamu (Muhammad) atas dosamu yang lalu dan yang akan datang serta menyempurnakan nikmat-Nya atasmu dan menunjukimu ke jalan yang lurus, dan agar Allah menolongmu dengan pertolongan yang kuat (banyak). Dialah yang telah menurunkan ketenangan ke dalam hati orang-orang mukmin untuk menambah keimanan atas keimanan mereka (yang telah ada). Dan milik Allah-lah bala tentara langit dan bumi, dan Allah Maha Mengetahui lagi Mahabijaksana. (QS. Al-Fath: 1-4)

\section{PEMBAHASAN}

\section{Analisis Surat Perjanjian Hudaibiyah Melalui Kemasan Jurnalistik}

Penegasan terhadap isi Perjanjian Hudaibiyah ini perlu dilakukan karena daya jangkau dari metode ini memang hanya pada hal-hal yang secara manifes ditunjukkan di dalam isi pesan (Perjanjian Hudaibiyah). Sesuai karakternya maka isi Perjanjian Hudaibiyah yang ada dalam kemasan jurnalistik merupakan sesuatu yang riil (nyata), bukan dalam alam pikiran, terekam baik dalam bentuk rekaman cetakan, pada tingkatan tertentu isi Perjanjian Hudaibiyah ini tidak akan dan tidak dapat berubah dan tidak memberi peluang bagi siapa saja peneliti untuk mengintervensi isi Perjanjian Hudaibiyah tersebut. ${ }^{44}$

Menganalisa setiap butir isi Perjanjian Hudaibiyah tersebut dan implikasinya, maka tidaklah terlalu berlebihan kalau dinilai bahwa Muhammad SAW. telah menggoreskan sejarah diplomasi melalui komunikasi politik tingkat tingginya yang luar biasa di depan Musyrikin Quraysi. Muhammad SAW sudah mengetahui betul karakter orang-orang Mekah, bahwa mereka akan melanggar perjanjian tersebut sebelum selesai 10 tahun.

Itulah sinyal penaklukan kota Mekah kemenangan paling gilang-gemilang bagi Muhammad SAW dan kaumnya melalui Perjanjian Hudaibiyah. ${ }^{45}$ Sebelum memasuki kota Mekah, Muhammad SAW memberi komando pasukannya supaya terbagi atas empat kelompok dan memasuki Mekah dari empat jurusan pula. Diperintahkannya pula supaya jangan sampai melakukan pertempuran. Hari ini, darah tidak boleh tumpah lagi, kecuali kalau sangat terpaksa. Dari segala penjuru, kota Mekah sudah dikepung oleh pasukan balatentaranya Muhammad SAW

\footnotetext{
${ }^{43}$ Muhammad Amahzun, Manhajun Nabiyy fì al-Da'wah ......., h. 238.

${ }^{44}$ Nunung Prajarto, analisis Isi Metode Penelitian Komunikasi. Cet.I; (Yogyakarta: FISIPOL UGM, 2010), h. 3-4.

${ }^{45}$ Ismail Pamungkas, Riwayat Nabi Muhammad 1. Cet. I; (Bandung: PT Remaja Rosdakarya, 1991), h. 11.
} 
sebanyak sepuluh ribu. Dan hari itu pula panji-panji Allah mulai berkibar di seluruh kota Mekah, dan akan terus berkibar selamanya. ${ }^{46}$

Dengan demikian, berkah Perjanjian Hudaibiyah membuka kesempatan untuk berdakwah secara leluasa. Sejak saat itu, Muhammad SAW bebas berdakwah hingga bisa berkirim surat ke raja-raja Persia, Romawi, Mesir untuk mengajak masuk Islam. Posisi Muhammad SAW begitu tinggi di mata dunia karena mengirim surat dan mengajak banyak pihak untuk masuk ke dalam agama Islam. Di masa tenang itu, banyak pihak yang mengakui kekuatan dan keagungan Muhammad SAW sehingga mereka memasuki agama Islam dengan mudah tanpa ada peperangan. ${ }^{47}$

Perjanjian Hudaibiyah telah mencatatkan diri Muhammad SAW sebagai diplomat atau juru runding yang sangat cemerlang dan layak diikuti, juru dakwah, politikus ulung yang mampu menjalankan nilai-nilai keislaman dalam bingkai kekuasaan dan pemerintahan.

\section{SIMPULAN}

Perjanjian Hudaibiyah adalah perjanjian antara kaum Muslimin Madinah dengan kaum musyrikin Mekah. Perjanjian yang ditandatangani di lembah Hudaibiyah, pada Maret, 628 M (Dzulqa'dah, 6 H). Hudaibiyah terletak 22 KM arah Barat dari Mekah menuju Jeddah.

Isi Perjanjian Hudaibiyah itu antara lain: (1) gencatan senjata antar kedua belah pihak selama 10 tahun supaya masyarakat hidup dengan aman dan damai. (2) Tahun itu kaum Muslimin tidak diperbolehkan mengunjungi Baitullah, mereka harus pulang ke Madinah. Tahun berikutnya baru boleh kembali ke Mekah untuk ibadah umrah. Dengan syarat, tidak membawa senjata kecuali yang biasa dibawa sehari-hari, dan diijinkan tinggal tidak lebih dari 3 hari. Selama 3 hari itu kaum Quraysi akan meninggalkan kota Mekah. (3) Kaum Muslimin harus memulangkan warga Mekah yang masuk Madinah kembali ke Mekah, namun ketentuan itu tidak berlaku sebaliknya. Orang Madinah yang ke Mekah tidak akan dikembalikan ke Madinah. (menurut ayat 10 dari Surah Al-Mumtahanah, ditetapkan tidak boleh memulangkan para mukminah Mekah yang datang ke Madinah kembali ke Mekah.(4) Seluruh kabilah sekutu Quraysi maupun Islam harus bebas dan merdeka.

Dalam perjanjian dengan Kafir Quraysi tersebut, keputusan yang dilakukan Muhammad SAW sangat tidak populis dalam pandangan para sahabatnya. Pada saat itu kondisi psikis Kaum Muslimin sangat tertekan. Mereka tidak percaya bahwa pemimpin mereka yang sangat cerdas mau menerima perjanjian itu begitu saja. Sikap lunak yang ditunjukkan Muhammad SAW

\footnotetext{
${ }^{46}$ Ismail Pamungkas, Riwayat Nabi Muhammad 1..., h. 11-12.

${ }^{47}$ https://www.nahimunkar.org/belajar-dari-perjanjian-hudaibiyah/
} 
membuat sebagian sahabat tidak terima dan menyampaikan kritik tajam. Bahkan ada yang berbicara keras dan bertanya dengan cara tidak sopan pada Muhammad SAW. Di antaranya Umar bin Khattab, dia bersikap kasar pada Muhammad SAW. Namun, Muhammad SAW dengan sabar mendengarkan intonasi tinggi Umar karena belum sepenuhnya mengetahui hikmahnya.

Pada saat itu, Muhammad SAW memerintahkan Kaum Muslimin untuk menyembelih hewan kurban yang telah mereka siapkan sebagai tanda berakhirnya ibadah Haji, tidak ada satupun yang melaksanakannya karena rasa heran \& marah lebih menguasai pikiran mereka.

Perjanjian Hudaibiyah, ternyata bukti kejeniusan komunikasi politik Muhammad SAW. Hikmanya adalah; (1) gencatan senjata pada dasarnya tidak dibutuhkan oleh Kaum Muslimin lagi, (2) jika penduduk Mekah tidak bisa menyebrang ke Madinah, artinya jumlah Kaum Muslimin tidak akan bertambah. Sekiranya para pelintas batas kaum kafir Quraysi harus ditahan di Madinah, maka akan memberikan beban ekonomi tambahan bagi masyarakat Madinah yang sudah kebanjiran pengungsi dari Mekah. Sebaliknya, para pelintas dari Madinah yang ditahan di Mekah akan dibiarkan, karena pasti mereka adalah para kader yang dapat melakukan upaya politik pecah belah di antara suku-suku yang ada di dalam masyarakat Quraysi. Selain itu, hikmahnya bahwa semakin banyak warga Madinah masuk Mekah, berarti kelak lebih memudahkan akan menunaikan haji. Muhammad SAW memang mengalah dalam perjanjian Hudaibiyah itu. Tapi sebenarnya, ia baru memperoleh kemenangan besar. Untuk pertama kalinya kaum Qurais mengakui keberadaan Islam secara resmi, dan mereka juga tak dapat lagi menolak umat Islam untuk berkunjung ke ka'bah tahun depannya. Muhammad telah mengalihkan bentuk perjuangannya dari perjuangan bersenjata ke perjuangan politik.

\section{Endnotes}

1. A. Muis, Komunikasi Islami. Cet. I; (Bandung: PT Remaja Rosdakarya, 2001), h. 39. Metakomunikasi adalah suatu komentar terhadap isi pembicaraan dan sifat hubungan antara yang berbicara, yaitu pesan di dalam pesan yang menyampaikan sikap dan perasaan pengirim terhadap pendengar.

2. Faisal Ismail, Sejarah \& Kebudayaan Islam; Periode Klasik (Abad VIIVIII M). Cet. I.; (Yogyakarta: IRCiSoD, 2017), h. 89.

3. Faisal Ismail, Sejarah \& Kebudayaan Islam..., h. 89.

4. Qadhi 'Iyâd Ibn Mûsa Al-Yahsubi, Muhammad Messengnge of Allah AshShifa of Qodi yang dialihbahasakan oleh Gufron A. Mas'adi dengan judul 
"Keagungan Kekasih Allah Muhammad SAW; Keistimewaan Personal Keteladanan Berisalah". Cet. I; (Jakarta: PT RajaGrafindo, 2002), h. 59.

5. Faisal Ismail, Sejarah \& Kebudayaan Islam..., h. 104. Ada saja sebagian kaum Orientalis Barat yang mengatakan bahwa gelar "Al-Amîn" itu diambil dari nama ibunya, yaitu Aminah. Apabila diteliti pendapat tersebut secara seksama, hal itu tidak mempunyai dasar sama sekali. Sebab pemberian nama atau gelar pada seseorang dengan nama ibu adalah tidak lazim bagi bangsa Arab. Tidak mustahil ada motif-motif tertentu yang bersifat tendensius pada sementara kaum Orientalis itu; mereka hendak menghapus dan mengaburkan sifat-sifat jujur dan pribadi luhur yang selalu memancar pada sosok pribadi Muhammad SAW.

Ilmuwan Sadillo yang dikutip Faisal Ismail mengatakan "Karena baiknya akhlak Muhammad terhadap masyarakat, Beliau pada usia 25 tahun diberi gelar Al-Amîn. Sementara William Muir mengatakan "bahwa Muhammad diberi gelar Al-Amîn dengan suara bulat oleh seluruh penduduk Mekah karena ketinggian budinya dan kemuliaan akhlaknya. Muir menerjemahkan kata Al-Amîn dalam bahasa Inggris, faithful. Lih. Faisal Ismail, Sejarah \& Kebudayaan Islam..., h. 104-105.

6. A. Muis, Komunikasi Islami..., h. 39

7. Badri Yatim, Sejarah Peradaban Islam. Cet. XXVIII; (Depok: PT RajaGrafindo Persada, 2017), h. 20.

8. Khâlid Muhammad Khâlid, Al-Insâniyah Muhammad yang dialihbahasakan oleh Salim Basyarahil dengan judul "Muhammad Rasulullah Juga Manusia Biasa”. Cet. I.; (Jakarta: Pustaka Firdaus, 1992), h. 25 .

9. Fuad Hashem, Sirah Muhammad Rasulullah Kurun Mekah. Cet. IV; (Bandung: Mizan, 1995), h. 136.

10. Khâlid Muhammad Khâlid, Al-Insâniyah Muhammad,... h. 3.

11. Mahmud Syalabi, Syakhshiyyah Rasûlullâh SAW. Cet. I.; (Beirut: Jamî'u Al-Huqûqi Mahfûzhati Lî Dâr Al-Jîl, 1412 H/1992), h. 13.

12. Anwar Arifin, Strategi Komunikasi; Sebuah Pengantar Ringkas. Cet. I; (Bandung: CV ARMICO, 1984), h. 13-14.

13. John Fiske, Introduction to Communication Studies yang dialihbahasakan oleh Hafsari Dwiningtyas dengan judul "Pengantar Ilmu Komunikasi". Cet. II. (Jakarta: PT RajaGrafindo Persada, 2012), h. 1.

14. B.N. Marbun, Kamus Politik. Cet. II; (Jakarta: Pustaka Sinar Harapan, 2003), h. 444-445.

15. Dan Nimmo, Political Communication and Public Opinion in America, yang dialihbahasakan oleh Tjun Surjaman dengan judul "Komunikasi Politik”. Cet. I; (Bandung: Remaja Karya CV Bandung, 1989), h. 8. 
16. Amin Rais, Refleksi Amin Rais: dari Persoalan Semut Sampai Gajah. Cet. I; (Jakarta: Gema Insani Press, 1997), h. 87.

17. Dan Nimmo, Political Communication and Public Opinion in America, yang dialihbahasakan oleh Tjun Surjaman dengan judul "Komunikasi Politik”. Cet. V; (Bandung: Remaja Karya CV Bandung, 1989), h. 86.

18. Undang A. Kamaluddin \& Muhammad Alfan, Dinamika Politik Di Indonesia: Perjalanan Politik Sejak Orde Lama Hingga Reformasi. Cet. I; (Bandung: Pustaka Setia, 2015), h. 37.

19. Titik Triwulan Tutik, Hukum Perdata dalam Sistem Hukum Nasional. Cet. I; (Jakarta: Kencana, 2010), h. 222.

20. Penyusun Departemen Ilmu Komunikasi Fakultas Ilmu-Ilmu Sosial Universitas Indonesia, Kamus Istilah Jurnalistik. Cet. I.; (Jakarta: Progres, 2003), h. 57.

21. Luwi Ishwara, Catatan-catatan Jurnalisme Dasar. Cet. III; (Jakarta: Buku Kompas, 2007), h. 17.

22. Suf Kasman, Pers dan Pencitraan Umat Islam di Indonesia; Analisis Isi Pemberitaan Kompas dan Republika. Cet. I; (Jakarta: Badan Litbang dan Diklat Kementerian Agama RI, 2010), h. 55.

23. Suf Kasman, Jurnalisme Universal; Menelusuri Prinsip-Prinsip Da'wah bi Al-Qalam Dalam Al-Qur'an. Cet. I. (Jakarta: Teraju, 2004), h. 55

24. Hisyam Muhammad Sa'id Barghisy, A'zham Insân 'Arafathu AlBasyariyyah, Akhlâquhu wa Kaifa Nuhibbuhu wa Nanshuruhu yang dialihbahasakan oleh Izzuddin Karimi dengan judul "Manusia Teragung Sepanjang Masa, Nabi Muhammad SAW; Potret Keagungan Akhlak dan Kepribadian Rasulullah SAW Serta Bagaimana Mencintai dan Membela Beliau. Cet. IV.; (Jakarta: Darul Haq, 2016), h. 3-4.

25. Washington Irfing, adalah salah seorang penulis besar Amerika yang menjadi kebanggaan Amerika Serikat dan negera-negara lain di abad ke XIX Masehi, lahir th. 1832 M. di kota Washington dan meninggal thn. $1892 \mathrm{M}$.

26. Jan Lek seorang orientalis Spanyol yang tersohor, lahir $182 \mathrm{M}$ dan wafat $1897 \mathrm{M}$

27. Loravicia Vaghleri, seorang orientalis perempuan asal Italia dan pengkaji sejarah Islam dan bahasa Arab, di antara buku-bukunya adalah Qawâ'id al'Arabiyah, Al-Islam dan Difa' an Al-Islâm.

28. Gustave Le Bon, seorang orientalis Perancis, lahir th. $1841 \mathrm{M}$, di antara buku-bukunya yang paling terkenal adalah Hadharah Al-'Arab, yang tergolong buku induk yang lahir di zaman modern di Eropa, buku ini menilai peradaban Arab Islam dengan obyektif, meninggal thn. $1921 \mathrm{M}$. 
29. George Bernard Shaw, seorang penulis alur cerita film dari Inggris yang terkenal, lahir di Irlandia, meraih Nobel di bidang sastra th. 1920 M.

30. Hisyam Muhammad Sa'id Barghisy, A'zham Insân 'Arafathu AlBasyariyyah, Akhlâquhu wa Kaifa Nuhibbuhu wa Nanshuruhu yang dialihbahasakan oleh Izzuddin Karimi dengan judul "Manusia Teragung Sepanjang Masa, Nabi Muhammad SAW; Potret Keagungan Akhlak dan Kepribadian Rasulullah SAW Serta Bagaimana Mencintai dan Membela Beliau. Cet. IV.; (Jakarta: Darul Haq, 2016), h. 4.

31. Fuad Hashem, Sirah Muhammad Rasulullah ..., h. 132.

32. David Benjamin Keldani (Abdul Ahad Dawud), Muhammad in the Bible yang dialihbahasakan oleh Burhan Wirasubrata dengan judul "Menguak Misteri Muhammad SAW". Cet. XIII; (Jatiwaringin, PT Sahara Intisains, 2006), h. 34.

33. Khâlid Muhammad Khâlid, Al-Insâniyah Muhammad,... h. 29.

34. Seyyed Hossein Nashr, Muhammadi Trust, Muhammad Man of Allah..., h. 48.

35. Qadhi 'Iyâd Ibn Mûsa Al-Yahsubi, Muhammad Messengnge of Allah...h. 7.

36. Qadhi 'Iyâd Ibn Mûsa Al-Yahsubi, Muhammad Messengnge of Allah...h. 8.

37. Tim Penyusun Naskah pada Proyek Pembinaan Perguruan Tinggi Agama/IAIN Alauddin Ujung Pandang tahun anggaran 1981/1982, h. 4344.

38. Seyyed Hossein Nashr, Muhammadi Trust, Muhammad Man of Allah..., h. 48-49.

39. Seyyed Hossein Nashr, Muhammadi Trust, Muhammad Man of Allah..., h. 49-50.

40. https://www.republika.co.id/berita/dunia-islam/islamdigest/18/07/27/pciqn8313-belajar-dari-hudaibiyah

41. https://islami.co/perjanjian-hudaibiyah-diplomasi-nabi-untuk-kerukunanmadinah-mekah/

42. Muhammad Amahzun, Manhajun Nabiyy fî al-Da'wah min Khilâli alSîrah al-Shahîhah: Al-Ma'rifah, al-Tarbiyah, Al-Thakhthîth, Al-Tanzhîm. Cet. I.; (Mesir: Dâr al-Salâm, 1423 H/2002), h. 233-236.

43. Muhammad Amahzun, Manhajun Nabiyy fì al-Da'wah ......., h. 238.

44. Nunung Prajarto, analisis Isi Metode Penelitian Komunikasi. Cet.I; (Yogyakarta: FISIPOL UGM, 2010), h. 3-4.

45. Ismail Pamungkas, Riwayat Nabi Muhammad 1. Cet. I; (Bandung: PT Remaja Rosdakarya, 1991), h. 11.

46. Ismail Pamungkas, Riwayat Nabi Muhammad 1..., h. 11-12.

47. https://urusandunia.com/perjanjian-hudaibiyah/ 
48. https://www.nahimunkar.org/belajar-dari-perjanjian-hudaibiyah/

\section{DAFTAR PUSTAKA}

Al-Yahsubi, Qadhi 'Iyâd Ibn Mûsa. Muhammad Messengnge of Allah Ash-Shifa of Qodi yang dialihbahasakan oleh Gufron A. Mas'adi dengan judul "Keagungan Kekasih Allah Muhammad SAW; Keistimewaan Personal Keteladanan Berisalah”. Cet. I; (Jakarta: PT RajaGrafindo, 2002).

Amahzun, Muhammad. Manhajun Nabiyy fì al-Da'wah min Khilâli al-Sîrah alShahîhah: Al-Ma'rifah, al-Tarbiyah, Al-Thakhthîth, Al-Tanzhîm. Cet. I.; (Mesir: Dâr al-Salâm, 1423 H/2002).

Arifin, Anwar. Strategi Komunikasi; Sebuah Pengantar Ringkas. Cet. I; (Bandung: CV ARMICO, 1984).

Barghisy, Hisyam Muhammad Sa'id. A'zham Insân 'Arafathu Al-Basyariyyah, Akhlâquhu wa Kaifa Nuhibbuhu wa Nanshuruhu yang dialihbahasakan oleh Izzuddin Karimi dengan judul "Manusia Teragung Sepanjang Masa, Nabi Muhammad SAW; Potret Keagungan Akhlak dan Kepribadian Rasulullah SAW Serta Bagaimana Mencintai dan Membela Beliau. Cet. IV.; (Jakarta: Darul Haq, 2016).

Barghisy, Hisyam Muhammad Sa'id. A'zham Insân 'Arafathu Al-Basyariyyah, Akhlâquhu wa Kaifa Nuhibbuhu wa Nanshuruhu yang dialihbahasakan oleh Izzuddin Karimi dengan judul "Manusia Teragung Sepanjang Masa, Nabi Muhammad SAW; Potret Keagungan Akhlak dan Kepribadian Rasulullah SAW Serta Bagaimana Mencintai dan Membela Beliau. Cet. IV.; (Jakarta: Darul Haq, 2016).

Fiske, John. Introduction to Communication Studies yang dialihbahasakan oleh Hafsari Dwiningtyas dengan judul "Pengantar Ilmu Komunikasi". Cet. II. (Jakarta: PT RajaGrafindo Persada, 2012).

Hashem, Fuad. Sirah Muhammad Rasulullah Kurun Mekah. Cet. IV; (Bandung: Mizan, 1995).

Ishwara, Luwi. Catatan-catatan Jurnalisme Dasar. Cet. III; (Jakarta: Buku Kompas, 2007).

Ismail, Faisal. Sejarah \& Kebudayaan Islam; Periode Klasik (Abad VII-VIII M). Cet. I.; (Yogyakarta: IRCiSoD, 2017). 
Kamaluddin, Undang A. \& Muhammad Alfan. Dinamika Politik Di Indonesia: Perjalanan Politik Sejak Orde Lama Hingga Reformasi. Cet. I; (Bandung: Pustaka Setia, 2015).

Kasman, Suf. Jurnalisme Universal; Menelusuri Prinsip-Prinsip Da'wah bi AlQalam Dalam Al-Qur'an. Cet. I. (Jakarta: Teraju, 2004). . Pers dan Pencitraan Umat Islam di Indonesia; Analisis Isi Pemberitaan Kompas dan Republika. Cet. I; (Jakarta: Badan Litbang dan Diklat Kementerian Agama RI, 2010).

Keldani, David Benjamin (Abdul Ahad Dawud). Muhammad in the Bible yang dialihbahasakan oleh Burhan Wirasubrata dengan judul "Menguak Misteri Muhammad SAW". Cet. XIII; (Jatiwaringin, PT Sahara Intisains, 2006).

Khâlid, Khâlid Muhammad. Al-Insâniyah Muhammad yang dialihbahasakan oleh Salim Basyarahil dengan judul "Muhammad Rasulullah Juga Manusia Biasa”. Cet. I.; (Jakarta: Pustaka Firdaus, 1992).

Marbun, B.N. Kamus Politik. Cet. II; (Jakarta: Pustaka Sinar Harapan, 2003).

Muis, A. Komunikasi Islami. Cet. I; (Bandung: PT Remaja Rosdakarya, 2001).

Nashr, Seyyed Hossein, Muhammadi Trust. Muhammad Man of Allah, yang dialihbahasakan oleh Bahtiar Effendi dengan judul "Muhammad Kekasih Allah; Perspektif Sufistik atas Sejarah Perjuangan Nabi”. Cet VI; (Jakarta: Hikmah, 2000).

Nimmo, Dan. Political Communication and Public Opinion in America, yang dialihbahasakan oleh Tjun Surjaman dengan judul "Komunikasi Politik". Cet. I; (Bandung: Remaja Karya CV Bandung, 1989).

Pamungkas, Ismail. Riwayat Nabi Muhammad 1. Cet. I; (Bandung: PT Remaja Rosdakarya, 1991).

Penyusun Departemen Ilmu Komunikasi Fakultas Ilmu-Ilmu sosial Universitas Indonesia, Kamus Istilah Jurnalistik. Cet. I.; (Jakarta: Progres, 2003).

Prajarto, Nunung, analisis Isi Metode Penelitian Komunikasi. Cet.I; (Yogyakarta: FISIPOL UGM, 2010)

Rais, Amin. Refleksi Amin Rais: dari Persoalan Semut Sampai Gajah. Cet. I; (Jakarta: Gema Insani Press, 1997).

Syalabi, Mahmud. Syakhshiyyah Rasûlullâh SAW. Cet. I.; (Beirut: Jamî’u AlHuqûqi Mahfûzhati Lî Dâr Al-Jîl, 1412 H/1992).

Tim Penyusun Naskah pada Proyek Pembinaan Perguruan Tinggi Agama/IAIN Alauddin Ujung Pandang tahun anggaran 1981/1982. 
Tutik, Titik Triwulan. Hukum Perdata dalam Sistem Hukum Nasional. Cet. I; (Jakarta: Kencana, 2010).

Yatim, Badri. Sejaraha Peradaban Islam. Cet. XXVIII; (Depok: PT RajaGrafindo Persada, 2017).

\section{WEB}

https://islami.co/perjanjian-hudaibiyah-diplomasi-nabi-untuk-kerukunan-madinahmekah/

https://urusandunia.com/perjanjian-hudaibiyah/

https://www.nahimunkar.org/belajar-dari-perjanjian-hudaibiyah/

https://www.republika.co.id/berita/dunia-islam/islam-digest/18/07/27/pciqn8313belajar-dari-hudaibiyah 